\title{
Urothelial cancer cell response to combination therapy of gemcitabine and TRAIL
}

\author{
JACOB A. MOIBI, ALLAN L. MAK, BO SUN and RONALD B. MOORE \\ Departments of Surgery and Oncology, Cross Cancer Institute, University of Alberta, Edmonton, Alberta, Canada
}

Received December 7, 2010; Accepted February 2, 2011

DOI: $10.3892 /$ ijo.2011.1023

\begin{abstract}
High-risk superficial urothelial carcinoma of the bladder (UCB) is commonly treated with intravesical bacillus Calmette-Guerin (BCG), but with significant side effects. We recently showed that the tumour necrosis factor-related apoptosis-inducing ligand (TRAIL) exhibited high therapeutic potential against UCB cells and with only limited toxic effects in normal cells. However, many cancer cells are refractory to TRAIL during monotherapy. Therefore, our experimental aim was to develop combinatorial approaches with other proapoptotic agents to reactivate apoptosis in resistant phenotypes. We demonstrate that UCB cells varied in their response to TRAIL, and the effect was caspase-dependent (reduced or abrogated by pre-incubation of cells with caspase-inhibitor peptides). In contrast wortmannin, a PI3K/Akt inhibitor, enhanced the TRAIL effect. Furthermore, combination therapy of TRAIL with low dose gemcitabine markedly enhanced UCB cell response (except in the TRAIL-resistant HT1376 cell line). The enhanced response was both time- and concentrationdependent and asymptotic at gemcitabine concentration $>1 \mu \mathrm{mol} / 1$. To define the mechanisms underlying gemcitabine-augmented TRAIL action, we evaluated the expression of several proteins regulating the apoptotic pathway. Gemcitabine-augmented TRAIL effect was associated with inhibition of the Bcl-2 protein (intrinsic signalling) along with activation of the caspase (extrinsic) cascade. The combined maximal stimulation of both the intrinsic and extrinsic signalling pathways also appeared to overcome the survival (PI3K/Akt) pathway as evident by the lack of response to wortmannin. Our semisolid multicellular-spheroid model showed that TRAIL and gemcitabine selectively caused UCB cells to undergo apoptosis without affecting normal cells, and both appeared to penetrate deeply enough to allow for combination intravesical therapy.
\end{abstract}

Correspondence to: Dr Ronald B. Moore, Division of Urology, Department of Surgery/Oncology, University of Alberta, 2D2.16 Walter Mackenzie Centre, 8440-112 Street, Edmonton, AB T6G 2B7 Canada

E-mail: rbmoore@ualberta.ca

Key words: bladder cancer, intravesical chemotherapy, gemcitabine, TRAIL

\section{Introduction}

The majority (80\%) of urothelial carcinomas (UC) are noninvasive. Recurrence of superficial UC of the bladder (UCB) is frequent (as high as 80\%) even after complete transurethral tumour resection [TURBT] (1). Bacillus Calmette-Guérin (BCG) is considered the most effective adjuvant intravesical treatment, and appears to induce tumour regression by host immune stimulation via tumour necrosis factor (TNF)-related apoptosis-inducing ligand [TRAIL] $(2,3)$. Systemic and intravesical cytotoxic chemotherapy is used to treat and prevent seeding at the time of TURBT, but BCG cannot be used immediately after TURBT or used systemically for invasive UC because of infectious complications. UC resistance to both BCG and cytotoxic chemotherapy can be induced. At a molecular level there is mechanistic rationale for combining these agents to target both the intrinsic and extrinsic apoptotic pathways. Unlike BCG, TRAIL can be combined with cytotoxic chemotherapy; hence we explored this further in an effort to identify a combinatorial treatment option that can selectively destroy only the transformed cells with minimal risk to normal tissues or the host.

A major mode of resistance to antitumour therapy is loss of sensitivity to apoptosis induction (4). Apoptosis is a cellular death program that controls tissue homeostasis $(5,6)$, and is tightly regulated by a variety of proapoptotic and antiapoptotic proteins; with the relative balance of the opposing activities determining cell fate. TRAIL, a member of TNF family, closely related to Fas-Ligand and TNF- $\alpha$, induces apoptosis in a wide variety of cancer cell lines and tissues. However, unlike FasLigand and TNF- $\alpha$, TRAIL spares normal cells even though most express TRAIL receptors at significant levels (7). Upon ligation to its death receptors (DR4 and DR5), TRAIL not only stimulates apoptosis via the formation of the Death Inducing Signalling Complex (DISC) that contains procaspase-8 and Fas Associated Death Domain (FADD) (8), but also activates NF- $\mathrm{KB}$, which regulates the expression of survival factors such as members of the inhibitors of apoptosis and the Bcl-2 families. Although TRAIL is quick at inducing apoptosis in many cancer cell lines, high concentrations of it are necessary to induce apoptosis in other cell lines with low-sensitivity. Cytotoxic chemotherapy and ionizing radiation can up regulate DR expression on cancer cells $(9,10)$. In addition, cytotoxic chemotherapy can trigger the mitochondrial (intrinsic) pathway 
$(4,11)$. Thus, combinations with chemotherapeutic agents may be necessary to sensitize UCB cells.

Gemcitabine $[\mathrm{dFdC}]$ is a nucleoside analog with broad spectrum activity against a variety of solid tumours. The cytotoxic effects of this agent are due to the ability of its diphosphate derivative to inhibit DNA synthesis; and the direct incorporation of gemcitabine into DNA, where it inhibits replication (12). Although clinical effectiveness has been demonstrated in the systemic treatment of advanced UC, both as monotherapy (13) and in combination with other agents (14), its use in combination therapy with TRAIL in UC has not been explored. The purpose of the study was to determine whether gemcitabine could sensitize UCB cells to TRAIL and thus potentiate TRAILinduced apoptosis in those cells that exhibit TRAIL resistance.

\section{Materials and methods}

Cell culture, spheroid preparation and reagents. Six established human bladder UC cell lines were used in the study: HT-1376 (ATCC, Manassas, VA, USA); UMUC-14 (from Dr H.B. Grossman, MD Anderson, Houston, TX, USA); 253J, T24, (from Dr M. Gleave, University of British Columbia, Vancouver, BC, Canada); RT112 and MGH-U3 (from Dr Y. Fradet, University Laval, QC, Canada). All cell lines were cultured at $37^{\circ} \mathrm{C}$ with $5 \% \mathrm{CO}_{2}$ (standard conditions) in RPMI-1640 or MEM medium supplemented with $10 \%$ fetal calf serum FCS, $10 \mathrm{mM}$ HEPES (RPMI only), sodium pyruvate, non-essential amino acids, $2 \mathrm{mM}$ L-glutamine, $100 \mathrm{U} / \mathrm{ml}$ penicillin, and $100 \mu \mathrm{g} / \mathrm{ml}$ streptomycin and $0.25 \mu \mathrm{g} / \mathrm{ml}$ amphotericin B. TRAIL-resistant (UC14-T1000) cells were obtained through stepwise exposure of the parental cells (UMUC-14) to $1000 \mathrm{ng} / \mathrm{ml}$ TRAIL (PeproTech Inc., Rocky Hill, NJ, USA). Gemcitabine was obtained from Eli Lilly (Indianapolis, IN, USA), reconstituted in sterile phosphate buffered saline and stored in aliquots at $-20^{\circ} \mathrm{C}$. A liquid overlay (semisolid) culture technique was used to produce multicellular spheroid culture (MCS) as previously described (15). Cells were seeded at a concentration of $3 \times 10^{3}$ cells/well in 96-well plates for tumour cells, and $6 \times 10^{3}$ cells/well for fibroblasts in $200 \mu \mathrm{l}$ of medium onto $1 \%$ solid agarose $(50 \mu \mathrm{l})$. After 3 days of culture, fibroblast MCS were transferred 1:1 with a pipette tip into a well with a tumour MCS. Resulting co-culture MCS (co-MCS) were ready for experimentation after 3-4 days. As previously reported (15), fibroblasts provide the optimal substrate to generate an in vitro co-cultured spheroid model with proper cellular orientation and cooperative paracrine growth with the malignant cell lines.

Bcl- $X_{L}$ phosphorothioate oligonucleotides. Antisense oligonucleotide to $\mathrm{Bcl}-2\left(\mathrm{Bcl}-\mathrm{X}_{\mathrm{L}}\right)$ chemically modified with phosphorothioates (ASO-Bcl2; from Dr. M Gleave and Oncogenex) was delivered into cells in the form of complexes with cationic lipid Lipofectin reagent (Invitrogen, Burlington, ON). ASO-Bcl2 and Lipofectin ${ }^{\circledR}$ reagent were mixed with $350 \mu \mathrm{l}$ of Opti-MEM in an Eppendorf tube. As well, $7 \mu 1$ of Lipofectin were diluted into $23 \mu \mathrm{l}$ of Opti-MEM in a second set of tubes and incubated at room temperature for $30 \mathrm{~min}$. Oligonucleotides and the Lipofectin/Opti-MEM mixtures were combined (ASO-LIPO complex) and incubated for additional $20 \mathrm{~min}$. The mixture was then allowed to dilute with complete growth medium to achieve final concentration of $1000 \mathrm{nM}$. Cells were incubated for $6 \mathrm{~h}$ at $37^{\circ} \mathrm{C}$ after which equal volumes of two times concentration of antibiotic-free, FCS-supplemented media were added, and cells were then cultured for additional $20 \mathrm{~h}$ before being treated with gemcitabine $(10 \mu \mathrm{M})$.

Dose-response relationship for gemcitabine-induced cell death. The growth inhibitory effects of TRAIL on UC cells during combination therapy with gemcitabine were tested in similar fashion to our recent paper on TRAIL dose-dependent UC cell death (16). Cells were seeded in 96-well plates at a density of 0.4 to $0.7 \times 10^{4}$ cells/well and cultured overnight to adhere to plate. Cells were then pulse-treated with varying concentrations of gemcitabine $\left(10^{-8}\right.$ to $\left.10^{-4} \mathrm{M}\right)$ without or with TRAIL (100 ng/ml) for $3 \mathrm{~h}$, after which the therapeutic medium was replaced with fresh drug-free media. After 24,48 or $72 \mathrm{~h}$ of culture (depending on experiment), cell survival was quantified using the tetrazolium dye 3-(4,5-dimethylthiazol-2-yl)-2,5diphenyltetrazolium bromide (MTT; Sigma-Aldrich, St. Louis, MO, USA). To determine the effect of caspase-3, -8, -9 and PI3K inhibitors on tumour cell growth, cells in 96-well plates were pretreated for $2 \mathrm{~h}$ with (all 2 times concentrated) $100 \mu \mathrm{l}$ $20 \mathrm{nM}$ wortmannin (to inhibit pro-survival growth factor signalling via PI3K/Akt pathway), or $40 \mu \mathrm{M}$ caspase inhibitory peptide IETD-fmk (for caspase-8) or $20 \mu \mathrm{M}$ DEVD-fmk (for caspase-3), or $20 \mu \mathrm{M}$ caspase inhibitory peptide Z-LEHD-fmk (for caspase-9) [Clontech, Mountain View, CA]. This was then followed by addition to the wells of (2 times concentrated) $100 \mu \mathrm{l}$ of $20 \mu \mathrm{M}$ gemcitabine or $200 \mathrm{ng} / \mathrm{ml}$ TRAIL or their combination (final concentrations were $10 \mu \mathrm{M}$ and $100 \mathrm{ng} / \mathrm{ml}$, respectively) and cells cultured for $48 \mathrm{~h}$ before MTT assay. For all experiments, cell death or growth inhibition was calculated as a percentage of the untreated controls. Each data point represents the average value from three experiments each of which was replicated at least four times.

Co-culture spheroid viability testing. Procedure for differentiating between the two cell populations of UC and fibroblasts, and their orientation in the co-MCS has been described (17), with the fibroblast occupying the inner core of the co-MCS. Untreated, gemcitabine- and/or TRAIL-treated co-MCS were labelled at 24 or $48 \mathrm{~h}$ post-treatment with nucleic acid stains $\mathrm{SYTO}^{\circledR} 16$ and propidium iodide (PI) for live/dead assay as previously described (17). Multiple fluorescent images of stained spheroids were captured using fluorescein isothiocyanate and Cy3 filters on a Zeiss Axioplan upright digital imaging microscope equipped with a SenSys cooled CCD camera (Photometrics, Tucson, AZ) using a Zeiss infinity corrected EC Plan-Neofluar 10x objective. All imaging parameters were identical, and acquired images were merged and processed with Metamorph ${ }^{\circledR}$ and Adobe Photoshop ${ }^{\circledR}$ CS2.

Determination of apoptotic cells by Annexin-V/PI and flow cytometry. Untreated or cells treated with gemcitabine and/or TRAIL were incubated with $80 \mu \mathrm{g} / \mathrm{ml}$ Hoechst 33342 $\left(\mathrm{C}_{27} \mathrm{H}_{37} \mathrm{C}_{13} \mathrm{~N}_{6} \mathrm{O}_{4}\right)$ for $1 \mathrm{~h}$ at $37^{\circ} \mathrm{C}$ under standard conditions, followed by Annexin-V -FITC (BD Biosciences, San Jose, CA) for additional $20 \mathrm{~min}$. Hoechst, stains the nuclei of live cells whereas membranes of apoptotic cells, but not of live cells are permeable to Annexin-V. The cell-dye suspension was fixed in $1 \%$ paraformaldehyde (PFA; in PBS), and image acquisition 

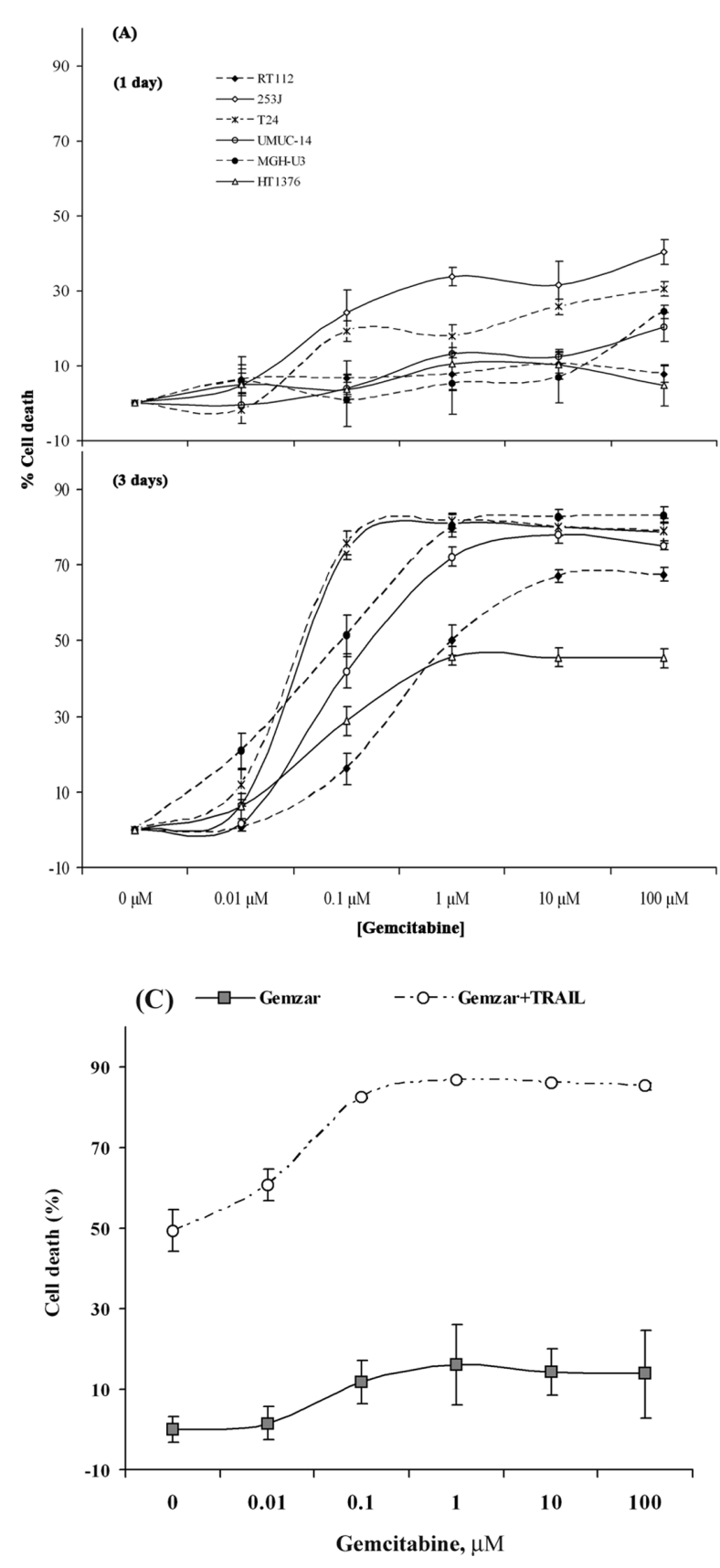

of 3-4 non-overlapping fields per well of a 24-well plate was performed on the Zeiss fluorescence microscope. Annexin-V and Hoechst-positive cells were counted after setting a threshold using Metamorph ${ }^{\circledR}$ software. The percentage of apoptotic cells (apoptotic ratio) was calculated as the ratio of the Annexinstained cells to total cell count (Annexin + Hoechst stained). For FACS analysis, after incubating with the various agents in vitro cells were collected by gentle trypsinization, washed with ice-cold PBS, and then $1 \times 10^{6}$ cells were fixed in $70 \%$ ethanol for $2 \mathrm{~h}$ at $4^{\circ} \mathrm{C}$. The pellet was resuspended in $1 \mathrm{ml}$ staining solution containing $20-\mu \mathrm{g} / \mathrm{ml} \mathrm{PI}$ and $375-\mu \mathrm{g} / \mathrm{ml}$ RNase A. Stained cells were incubated at room temperature for $30 \mathrm{~min}$ (in the dark), and the cellular DNA content analyzed by flow cytometry. The relative percentage of DNA content in the sub-G1 phase was then quantitated and used as an estimate of cells undergoing apoptosis (18).
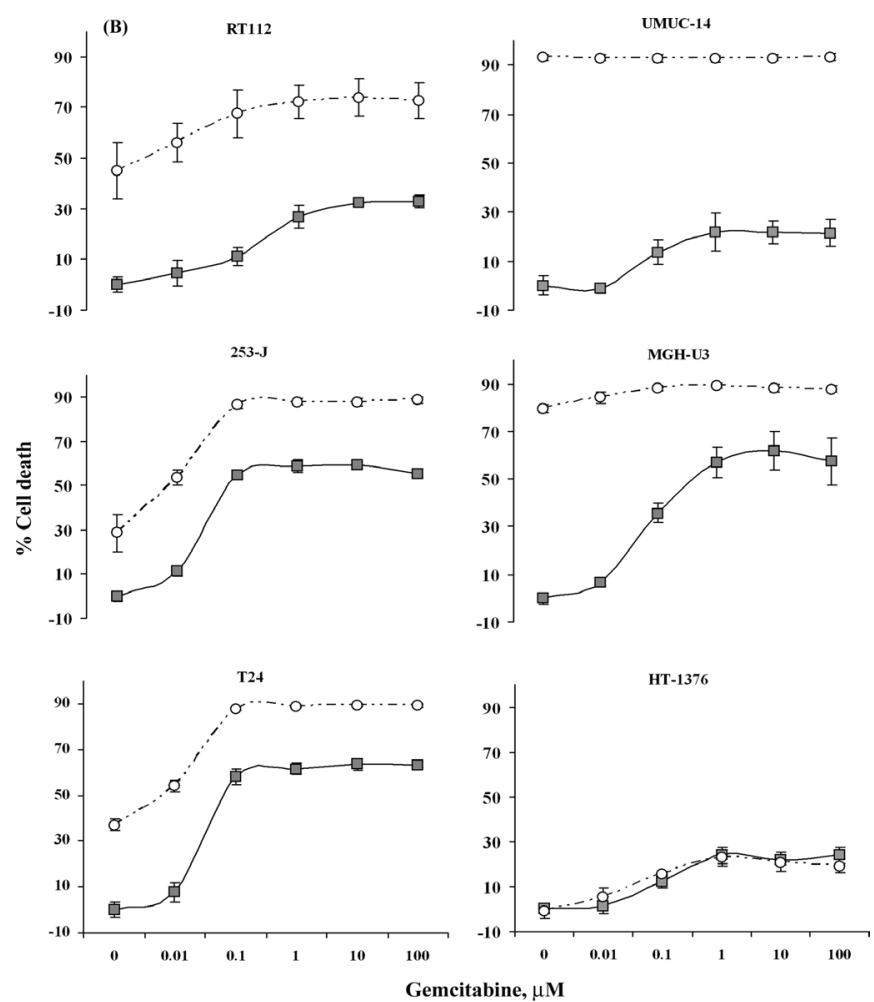

$\multimap-$ Gemzar - o- Gemzar + TRAIL

Figure 1. Cytotoxicity, and differential responses of UCB cell lines to gemcitabine and TRAIL. (A) Six UCB cell lines were each seeded in 96-well plates $\left(5 \times 10^{3} /\right.$ well) and allowed to grow overnight. Cells were then treated once with gemcitabine ( 0.1 to $100 \mu \mathrm{M})$ for $4 \mathrm{~h}$ followed by 1-day or 3-day culture in drug-free medium before MTT assay. (B) After cells were treated with gemcitabine (for $4 \mathrm{~h}$ as in $\mathrm{A}$ ) the therapeutic medium was replaced with a drug-free medium and cells were cultured overnight. Cells were next treated with TRAIL $(100 \mathrm{ng} / \mathrm{ml})$ for $4 \mathrm{~h}$ and were then cultured for a further $20 \mathrm{~h}$ in a drug-free medium followed by MTT assay. (C) Partially TRAILresistant cells (EP-UC14-1000) obtained through stepwise exposure of UMUC-14 cells to $1000 \mathrm{ng} / \mathrm{ml}$ TRAIL were pre-exposed to gemcitabine followed by TRAIL treatment as described for (B). Values shown are the mean percent cell deaths $( \pm$ SEM) of at least 3 separate experiments each with multiple replications (SEM values smaller than the symbol size are not visible).

Immunoblotting. Following in vitro treatment with gemcitabine and/or TRAIL, cells were lysed in buffer containing $50 \mathrm{mM}$ HEPES [pH 8.0], $150 \mathrm{mM} \mathrm{NaCl}, 1 \%$ Triton X-100, $5 \mathrm{mM}$ EDTA, $5 \mathrm{mM}$ EGTA, $20 \mathrm{mM}$ sodium pyrophosphate, $1 \mathrm{mM}$ sodium orthovanadate, $10 \%$ glycerol, $1 \mathrm{mM}$ phenylmethylsulfonyl fluoride, and $4 \mu \mathrm{g} / \mathrm{ml}$ each of leupeptin, aprotinin and pepstatin A. Protein amounts of postnuclear supernatants were assayed using BCA (Pierce, Rockford, IL). Aliquots containing $40 \mu \mathrm{g}$ of protein were then separated on 4-15\% SDS-polyacrylamide gels and electrophoretically transferred to nitrocellulose membranes (Bio-Rad, Hercules, CA). After blocking, membranes were incubated with primary antibodies directed against Bcl-2 (Upstate, Charlottsville, VA), Bid, PARP, and caspases-3, -8 and -9 (Cell Signaling) followed by their respective horseradish-peroxidase-conjugated secondary antibodies (Jackson ImmunoResearch, West Grove, PA). Immunoreactive proteins were detected by echo-chemiluminescence and autoradiography using HyperFilm-ECL (Amersham, Buckinghamshire, UK). Stripped blots were reprobed with 
anti-tubulin or mouse anti- $\beta$-actin IgG (Sigma) to establish equivalent loading.

Statistical analysis. Data are provided as means \pm SEM. The in vitro cytotoxic effects of gemcitabine and/or TRAIL were analyzed using an ANOVA model. Association between the expression levels of anti-apoptotic proteins and percent celldeath was analyzed using the Spearman rank correlation. All statistical tests were two-sided, and the level of significance was set at $\mathrm{p}<0.05$. All analyses were performed using GraphPad Prism $^{\circledR}$.

\section{Results}

Differential sensitivity of UCB cells to gemcitabine and TRAIL treatment. We exposed UCB cell lines to escalating concentrations of gemcitabine (from 0.01 to $100 \mu \mathrm{M}$ ) for $4 \mathrm{~h}$ (a relevant clinical intravesical dwell time) and measured cell death by MTT. As depicted in Fig. 1A, gemcitabine cytotoxicity on UC was time-dependent and increased dramatically from 24 to $72 \mathrm{~h}$. At $24 \mathrm{~h}$ post treatment, UC cells displayed minimal response at all gemcitabine concentrations. However, when cells were cultured for $72 \mathrm{~h}$ there was marked increase in cell death $(p<0.05)$, even at the low gemcitabine concentrations suggesting that both concentration and temporal effects are important in eliciting gemcitabine effect. The time $\mathrm{x}$ concentration interaction was further examined in cells treated with gemcitabine for 3 consecutive days ( $4 \mathrm{~h} /$ day; multiple dosing) compared with single dosing above. We observed that the single-dose gemcitabine was as effective as the multiple doses at inducing UC cell death (data not shown), further confirming the timedependence of gemcitabine effect.

Gemcitabine was previously reported to sensitize pancreatic cancer cells to TRAIL-mediated killing (19). Therefore, in combination experiments we pulse-treated UC cells with escalating concentrations of gemcitabine for one day followed by TRAIL [100 ng/ml; optimal concentration determined in prior studies (16)] treatment for an additional day (Fig. 1B). Treatment with TRAIL as a single agent significantly increased cell deaths by $30-95 \%$ in all cell lines (except in HT-1376) relative to untreated control. We have recently reported that these same cell lines displayed differential responses to TRAIL, with UMUC-14 and MGH-U3 being sensitive; RT112, 253J and T24 partially resistant; and HT-1376 being resistant to TRAIL (16). Thus our current data is consistent with this prior observation. In combination experiments, partially TRAILresistant cells treated with gemcitabine followed by TRAIL showed an enhancement in cell death $(\mathrm{p}<0.05)$ that is beyond that seen for TRAIL alone. Combination of gemcitabine with TRAIL did not improve TRAIL sensitivity in the resistant HT-1376 cell line. However, in UMUC-14 cells made partially TRAIL-resistant through stepwise exposure to $1000 \mathrm{ng} / \mathrm{ml}$ TRAIL (UC14-T1000), gemcitabine presensitization reactivated TRAIL sensitivity in these cells (Fig. 1C). Epifluorescent microscopy (Hoeschst 33258 / Annexin V staining) and FACS analysis showed that gemcitabine inhibited the growth of UC cells in a time-dependent manner (increased apoptosis at 2 days post-treatment vs one day; Fig. 2A), and that UC cells underwent gemcitabine induced TRAIL-mediated apoptosis as a method of cell death. In the presence of TRAIL or gemcitabine
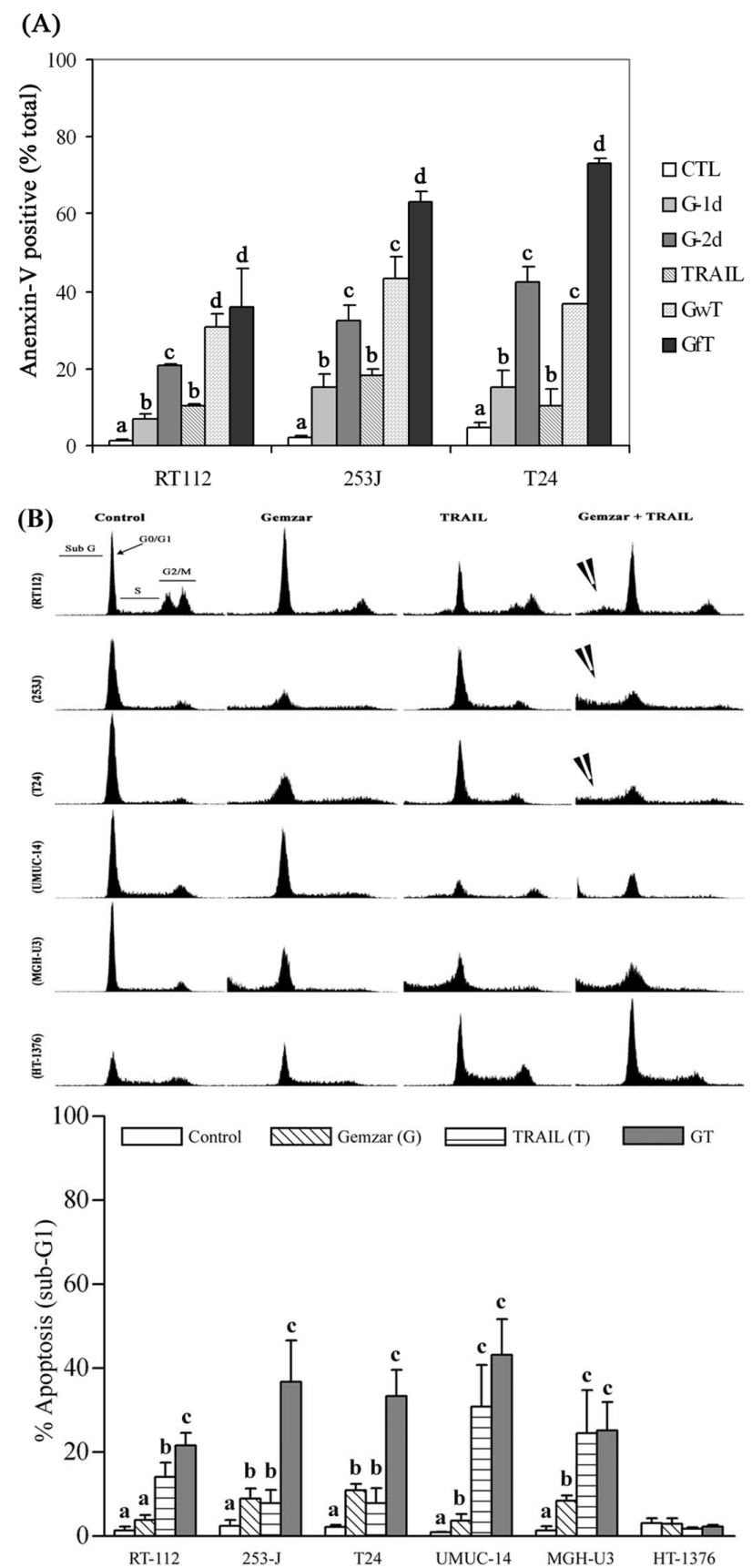

Figure 2. Therapy-induced apoptosis as determined by Annexin-V staining and flow cytometry. UCB cells grown in 24-well plates were treated for $4 \mathrm{~h}$ with gemcitabine $(10 \mu \mathrm{M})$ and/or TRAIL $(100 \mathrm{ng} / \mathrm{ml})$ and then cultured overnight in drug free medium. Cells were then fixed and stained with Hoechst 33342, and Annexin-V for epifluorescence microscopy (A) or stained with PI for flow cytometry analysis (B, representative experiments). CTL, control; G-1d and G-2d, gemcitabine, one day or 2 days; GwT, cells treated with gemcitabine and TRAIL simultaneously; GfT, cell treated with gemcitabine for one day followed by TRAIL. Arrowheads are to highlight increases in proportion of cells in the sub-G region (hence increased apoptosis) during combination treatment of Gemzar and TRAIL in RT112, 253J and T24 (all partially TRAIL resistant) cell lines. a-d, different letters within each cell line group are significantly different, $\mathrm{p}<0.05$.

alone there was increased accumulation of sub-G1 fraction in all cell lines except HT-1376 when compared with the control (Fig. 2B, top panel). Combination of the two agents increased the sub-G1 fraction in the partially TRAIL resistant cells more than individual effect alone. 


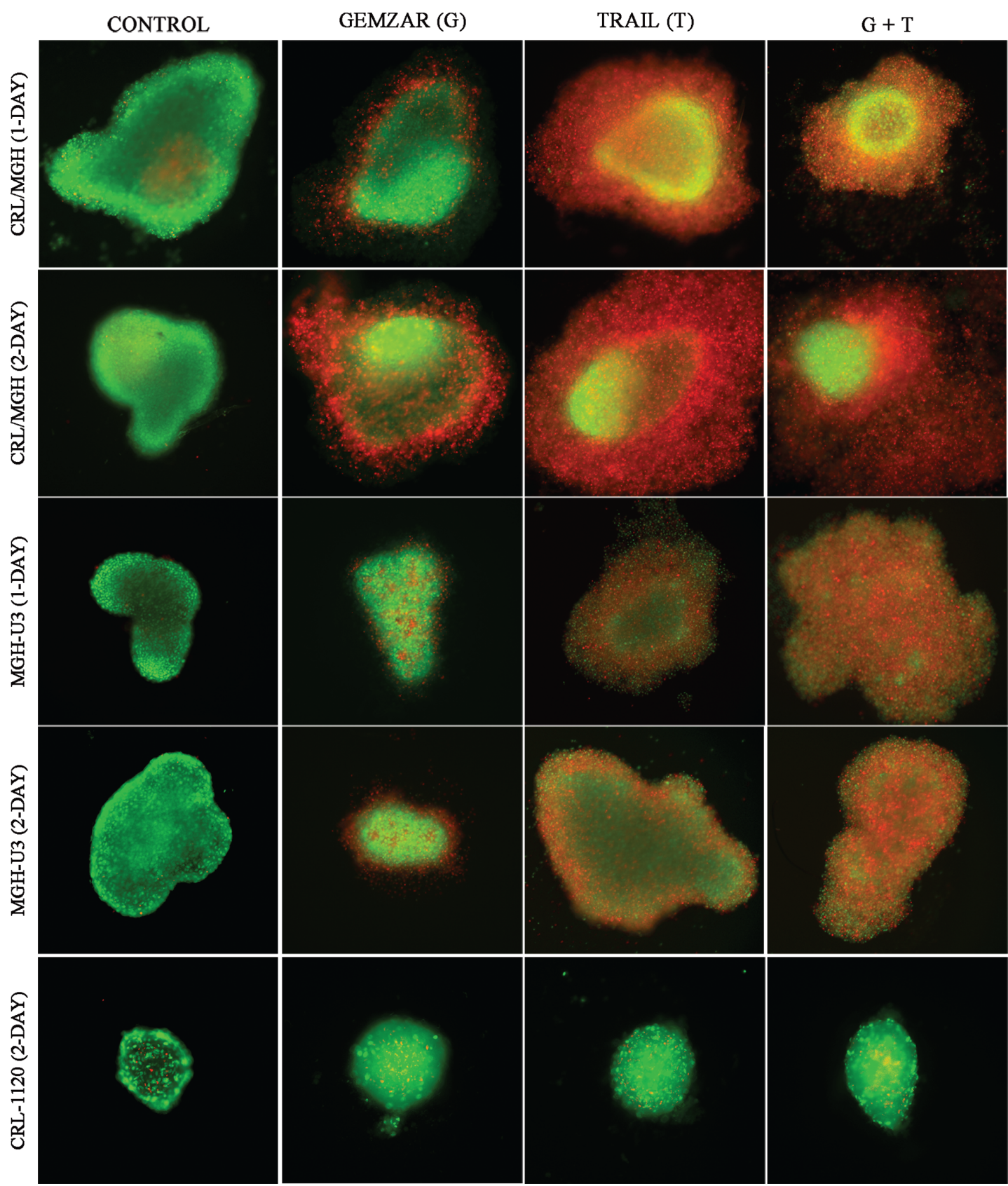

Figure 3. Vital staining for selective cytotoxicity of gemcitabine and TRAIL during combination therapy (red, dead; green, live). Vital dye (SYTO-16/PI) staining of single (MGH-U3 or CRL-1120) and co-cultured spheroids (MGH-U3/CRL-1120), demonstrating the selective cell killing by gemcitabine and/or TRAIL. Spheroids (single or co-cultured) were treated with gemcitabine $(10 \mu \mathrm{M})$ and/or TRAIL $(100 \mathrm{ng} / \mathrm{ml})$ followed by staining. Image acquisition described under Materials and methods.

Next we examined whether the two agents can selectively produce cytotoxicity in a co-MCS setting while sparing normal cells. The MCS model provides in vitro simulation of tumour micro-environment and has been used extensively in prior studies of resistance of tumour cell layers to chemotherapy. Pure and co-MCS (MGH-U3 and CRL-1120 fibroblasts) were exposed to gemcitabine $(10 \mu \mathrm{M})$ alone or with TRAIL (100 ng/ml), and cell death and shedding (MCS dissolution) were monitored (Fig. 3). In homogeneous spheroids (comprised exclusively of MGH-U3), PI uptake by gemcitabine- or TRAILtreated cells increased dramatically from 24 to $48 \mathrm{~h}$; an indication of increased cell death. Similarly, in heterogeneous co- MCS (MGH-U3/CRL-1120) the PI uptake was time-depen- dent for the peripheral MGH-U3 cells whereas CRL-1120 fibroblasts took up SYTO 16 dye, indicating tumour-specific gemcitabine-initiated cell death and dissolution. Furthermore, combination of the two agents produced marked UC cell killing and extensive dissolution compared with either agent alone. There were no cytotoxic effects observed on the fibroblasts. Collectively these results suggest that the combination of TRAIL and gemcitabine caused rapid cell death, and selectively cause UC cells to undergo apoptosis in co-MCS without affecting normal fibroblasts.

Apoptosis response of UC cells to gemcitabine/TRAIL is dependent on suppression of Bcl-2 and activation of the 

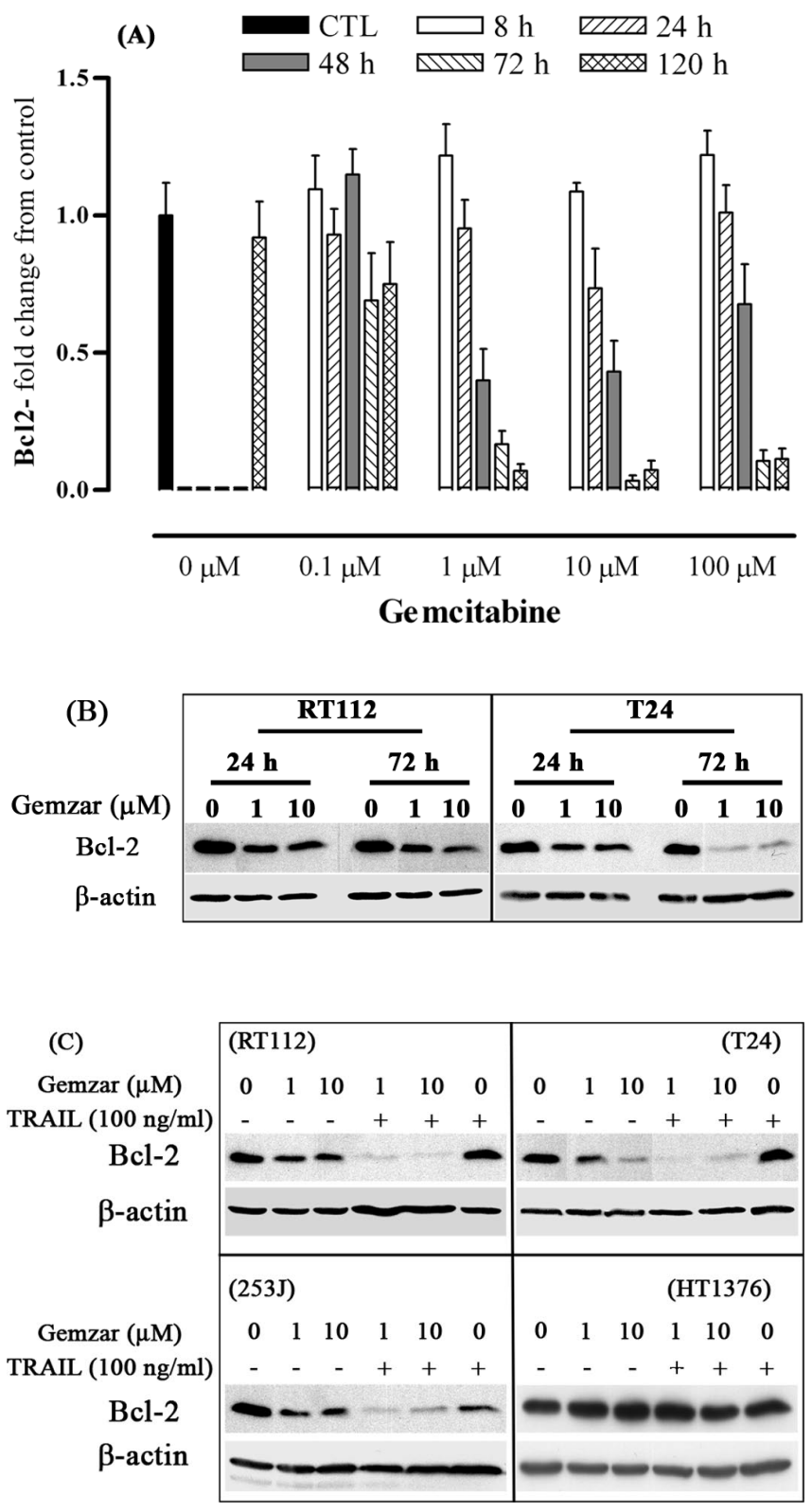
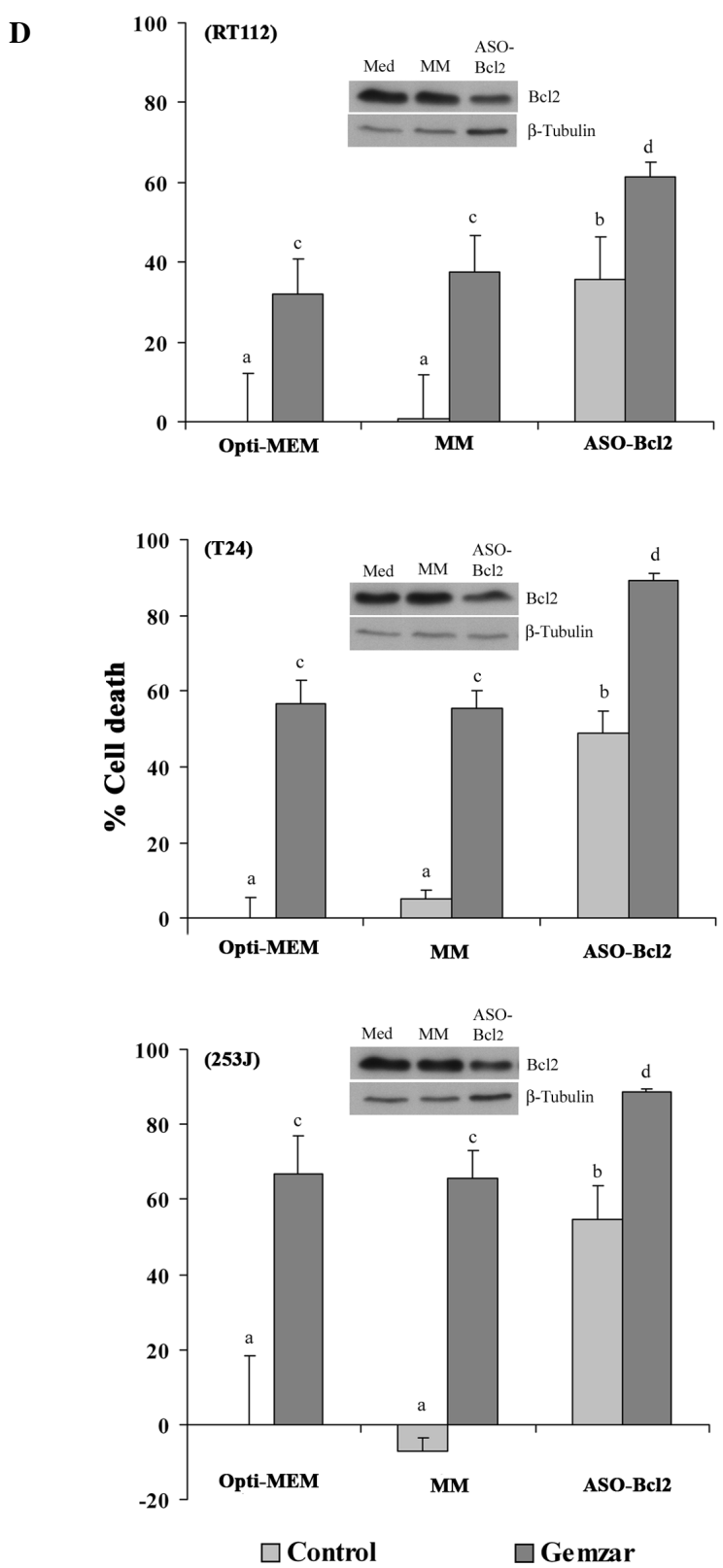

Figure 4. Effect of gemcitabine and TRAIL on Bcl-2 expression. (A) Shows arbitrary densitometry values, respectively for Bcl-2 protein expression in RT-112 cells after exposure to varying concentrations of gemcitabine for the time indicated. Data are the means \pm SEM from three separate experiments; (B) shows immunodetectable Bcl-2 protein in gemcitabine-treated RT112 and T24 cell lines harvested at 24 or 72 h post-treatment; and (C) expression levels of Bcl-2 protein in TRAIL-resistant (HT-1376) and partially TRAIL-resistant (RT112, T24, 253J) UCB cell lines after combination therapy with gemcitabine and TRAIL. Cells were treated with the agents for $4 \mathrm{~h}$ and then cultured in drug-free medium for 3 days before harvesting for Western blot analysis. $\beta$-actin was used as loading control. (D) Partially TRAIL responsive cell lines (RT112, T24 and 253J) were transfected with antisense oligonucleotide targeting Bcl-2 (ASO-Bc12) or MisMatch control (MM). Twenty-four hours after transfection cells were treated with gemcitabine (10 $\mu \mathrm{M}$ for $4 \mathrm{~h}$ ) and then cultured for 2 days in drug-free medium followed by MTT cell proliferation assay. Western blot analysis showed that ASO-Bcl-2 reduced Bcl-2 expression in the treated cells. a-d represent significant differences, $\mathrm{p}<0.05$.

caspase pathway. Next we examined changes in the expression of key proteins that are centrally involved in regulating apoptosis. Most death modulators function by acting through the Bcl-2 family. Although other members of this family stimulate programmed cell death, bcl-2 is the prototypic antiapoptotic gene (20), and its expression has been correlated with apoptotic responses of a variety of neoplastic cell lines. Gemcitabine alone decreased Bcl-2 expression in the partially-TRAIL resistant cell lines, and the effect was both time and concentration dependent (Fig. 4A-C). TRAIL alone had little or no effect on
Bcl-2 expression in the same partially TRAIL-resistant cell lines. However, when TRAIL was combined with gemcitabine the decrease in Bcl-2 expression was more pronounced than the gemcitabine effect alone. Further analysis showed that Bcl-2 level was inversely correlated with gemcitabine cytotoxicity (percent cell death) in UC cell lines consistent with Bcl-2 being prognostic of tumour recurrence and progression (21-23). The inverse relationship prompted us to examine whether downregulation of $\mathrm{Bcl}-2$ (thus altering the ratio of antiapoptotic-to-apoptotic proteins) would lead to decreased 

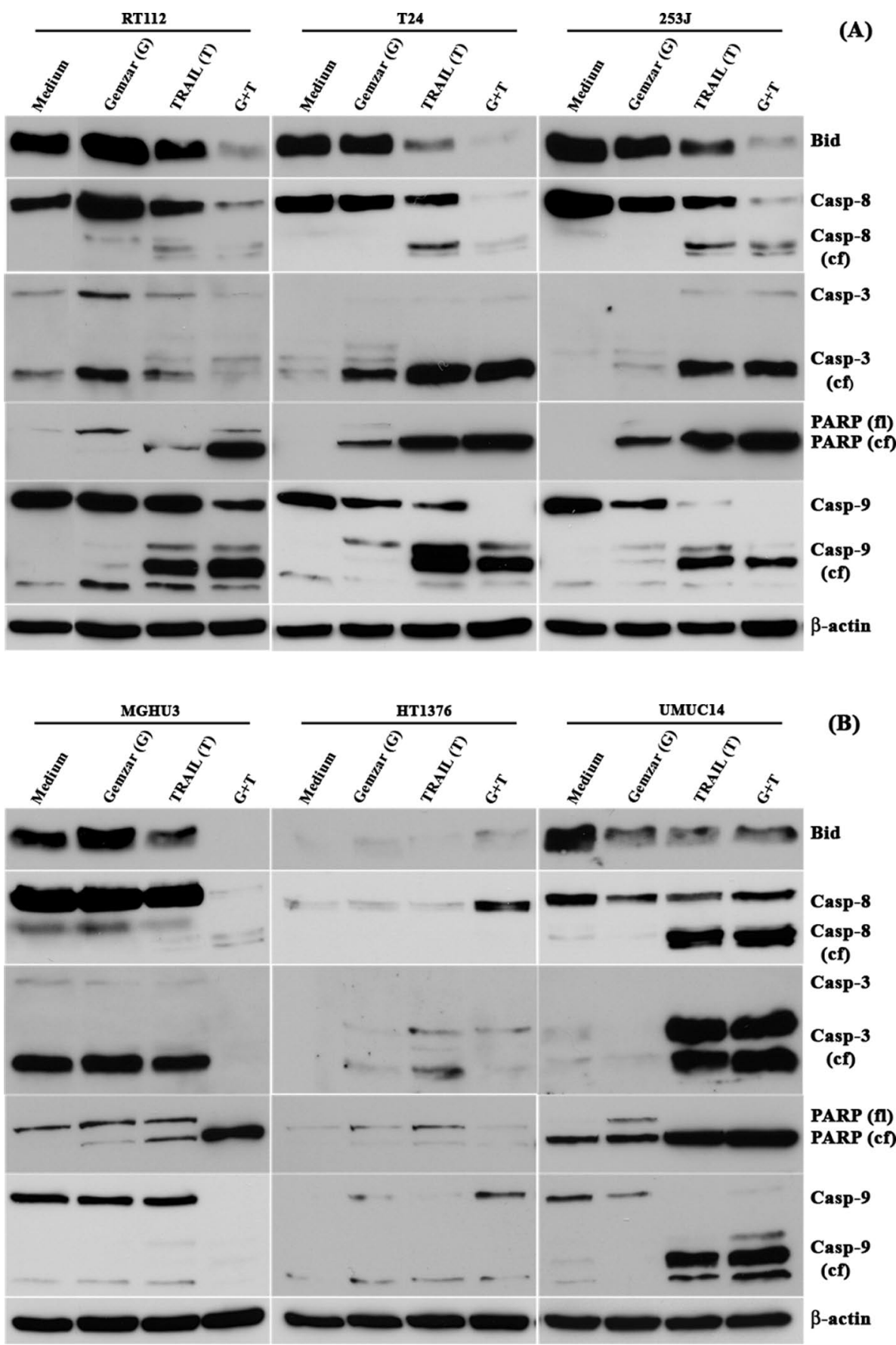

Figure 5. Effect of gemcitabine and its combination with TRAIL on apoptotic protein expression in UCB cells. Cells were exposed to $10 \mu \mathrm{M}$ gemcitabine for $4 \mathrm{~h}$ and then incubated in drug-free media for additional $20 \mathrm{~h}$ followed by TRAIL treatment $(100 \mathrm{ng} / \mathrm{ml}$ for $4 \mathrm{~h})$. Cells were harvested immediately following TRAIL treatment and lysates examined by Western blot analysis using a panel of antibodies directed against Bid, PARP, caspase- $8,-3$ and -9 . Equal protein loading of samples was verified by the level of $\beta$-actin in stripped blots ( $25 \mathrm{mM}$ glycine, $\mathrm{pH} 2.0,1 \%$ SDS).

apoptotic resistance and/or improved tumour cell response to the cytotoxic agent. We transiently transfected 3 partiallyTRAIL-resistant cell lines (RT112, T24, and 253J) with antisense oligonucleotide to $\mathrm{Bcl}-2$ (ASO-Bcl2) or mis-match control (MM) and cultured them in the absence or presence of gemcitabine $(10 \mu \mathrm{M})$. Western blot analysis showed that ASO-Bcl 2 treatment greatly reduced $\mathrm{Bcl}-2$ protein expression (Fig. 4D) along with increased cell death compared with the $\mathrm{MM}$ control. Combination of ASO-Bcl2 and gemcitabine significantly increased cell death compared with either gemcitabine or ASO-Bcl2 alone.

We also analyzed caspase-mediated Bid activation in partially TRAIL resistant and TRAIL-sensitive cells. Gemcitabine effect on Bid expression was somewhat variable and did not show strong relationship with treatment. However, we detected greatly reduced levels of Bid (suggesting consumption of Bid protein by caspase- 8 during activation) after treatment with TRAIL alone [similar to our recent observation 

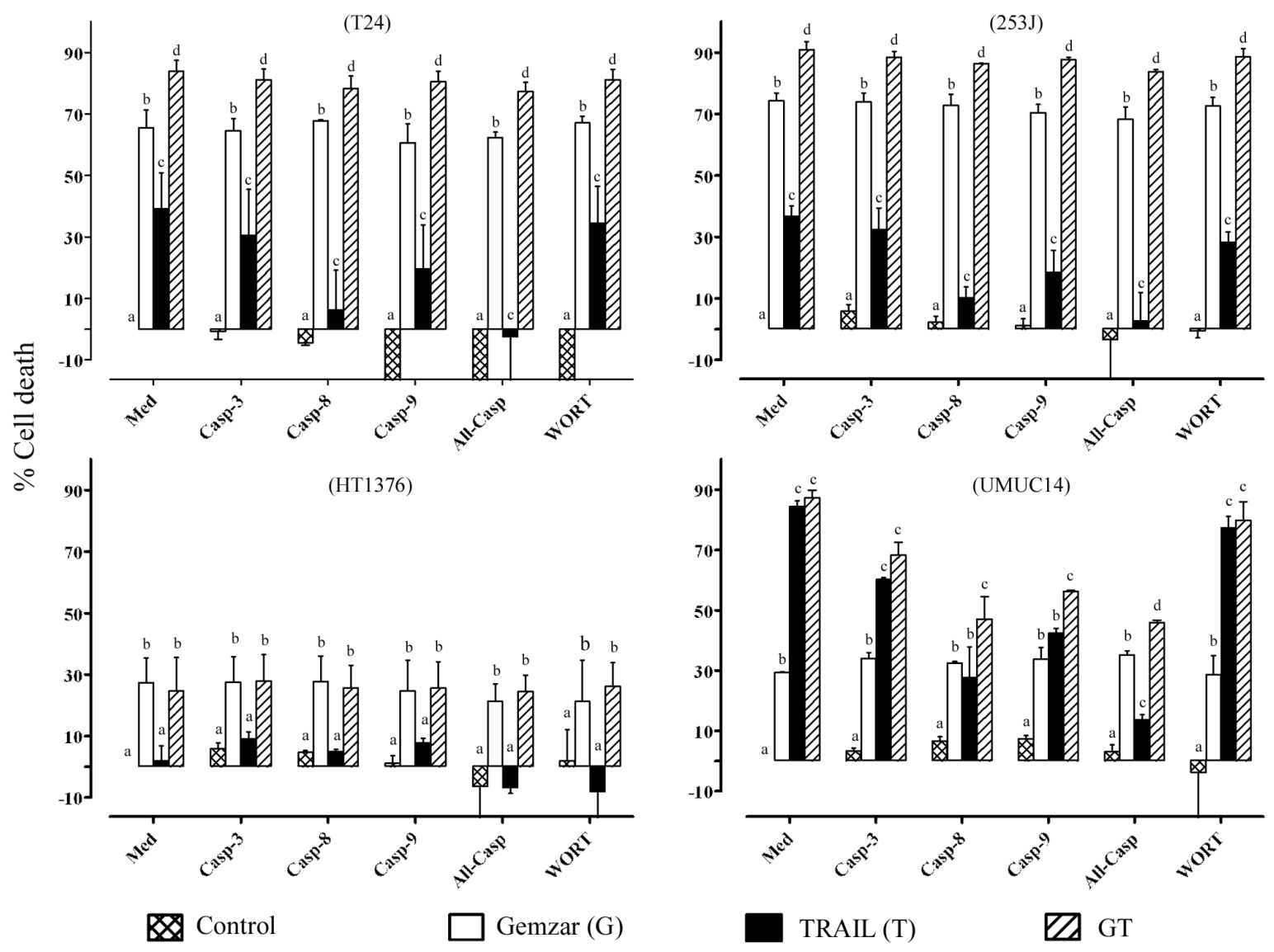

Figure 6. Effect of PI3K/Akt and caspase inhibitors on cell death. HT1376 (TRAIL resistant), T24, 253J (both partially TRAIL resistant) and UMUC14 (TRAIL sensitive) cells were pretreated with $10 \mu \mathrm{mol} / 1$ of caspase-3 inhibitor DEVD-fmk (CASP3-PEP) or $20 \mu \mathrm{mol} / 1$ of the caspase-8 inhibitor IETD-fmk (CASP8-PEP) or $20 \mu \mathrm{mol} / 1$ caspase-9 inhibitor Z-LEHD-fmk (CASP9-PEP) or all three combined or $10 \mathrm{nmol} / 1$ Wortmannin (WORT) for $2 \mathrm{~h}$ and then further cultured with $2 \mathrm{X}$ TRAIL (final concentration $=100 \mathrm{ng} / \mathrm{ml}$ ) or $2 \mathrm{X}$ gemcitabine (final concentration $=10 \mu \mathrm{M}$ ) for $48 \mathrm{~h}$ after which cell viability was measured by MTT. Data are means of cell death (expressed as a percentage of control) \pm SEM from two independent experiments. a-d within each assay group (med, casp-3, casp-8, etc.) are significantly different, $\mathrm{p}<0.05$.

(16)] or in combination with gemcitabine (Fig. 5A and B). We did not observe an active fragment of Bid (tBid) in any of the treatments. Also gemcitabine-augmented TRAIL-induced caspase-8, -9 and -3 activation was enhanced in the cell lines (except HT1376). Further, we observed enhanced PARP cleavage in response to gemcitabine and during combination therapy with TRAIL. These results could mean that both the extrinsic and intrinsic pathways were involved in the apoptotic cell death initiated by gemcitabine/TRAIL. On the other hand there was little or no activation of Bid, PARP, procaspase-8, -3 and -9 in the TRAIL-resistant HT-1376 cell line (Fig. 5B); suggesting there could be a defect upstream of caspase activation, which may result in failure to adequately activate and initiate apoptotic signalling in this cell line. To further investigate the involvement of the caspases in gemcitabine- and TRAILinduced cell death, we pre-treated cells with caspase inhibitor peptides before exposing them to gemcitabine and/or TRAIL. Addition of individual caspase inhibitor peptides or their combination significantly inhibited TRAIL-induced cell death (Fig. 6), supporting that the observed TRAIL effects were directly dependent on the activation of these caspases. However, inhibition of the caspases was not effective in diminishing gemcitabine cytotoxicity. Also, inhibition of the pro-survival function via wortmannin inhibition of PI3K/Akt had very little to no effect on TRAIL- or gemcitabine-induced cell death or when gemcitabine was combined with TRAIL (Fig. 6).

\section{Discussion}

UC response to BCG is believed to be mediated by TRAIL. TRAIL induces apoptosis in a variety of tumour cells with minimal toxicity to normal cells. Resistance to TRAIL-mediated apoptosis by some tumour cells however limits its widespread application. Several factors have been implicated in this resistance. Amongst them is the low expression of agonistic TRAIL receptors DR4 and DR5, but there does not appear to be a common mechanism for all cancer cells (15-17). Recently we showed that the TRAIL-induced apoptosis is mediated via activation of caspase- 3 and -8 in UC cells (16), which is often a function of ligand-dependent trimerization of DR4 and DR5 and the efficiency by which TRAIL ligation to the DRs induces protein association in the caspase cascade. In some experiments we observed that UC cell lines that are less responsive to TRAIL express DR4 and DR5 receptors at levels comparable to the TRAIL-sensitive ones (data not shown). That is, the apoptotic sensitivity of the UC cells did not appear to be related to the DR expression patterns alone (27-29). Thus, our current observation that TRAIL induced apoptosis in a caspase- 
dependent fashion may suggest that resistance to TRAIL may depend more on the level of intracellular signalling molecules rather than differences in receptor expression.

Given our prior data (15-17) we have focused on identifying effective therapeutic strategies for overcoming resistance within heterogeneous and adaptive solid tumour cell population, with the view that multiple apoptotic pathways (the extrinsic and intrinsic) would need to be targeted. Recent studies in the literature have indicated that sequential treatment of tumour cells with combination of TRAIL and chemotherapy can overcome resistance to TRAIL-mediated apoptosis, and in particular significant synergism between TRAIL and gemcitabine action has been demonstrated in other cancer cell lines (27,30,31). In the current studies we investigated the utility of combining gemcitabine with TRAIL for the treatment of localized (nonmuscle invasive) and possibly advanced (invasive) bladder cancer. In the normally TRAIL-resistant UC (HT1376) cells, pretreatment with gemcitabine did not overcome resistance of the cells to TRAIL-induced apoptosis. This is discordant with the observation by Seol et al (32) that showed pretreatment of TRAIL-resistant A549 cells with gemcitabine enhanced TRAIL-induced apoptosis, which was mediated not only via caspase-dependent and mitochondrial pathway but also by upregulating DR5 expression. Consistent with other studies $(32,33)$ however, we showed that gemcitabine induced apoptosis in the partially-TRAIL-resistant bladder UC cells, and its anti-proliferative effects were concentration-dependent. Also, we observed significant enhancement of cytotoxicity in nearly all UC cells through rapid induction of apoptosis when co-treated with gemcitabine and TRAIL. These observations, like other similar observations in the literature $(19,32,34,35)$, could be of clinical importance in that TRAIL could serve to sensitize cancer cells to chemotherapeutic agents or vice versa and thus enable dose reduction and therefore reduce side effects $(36,37)$. Also concentrations of gemcitabine required to sensitize UC cells to TRAIL-mediated apoptosis are well within a range that is clinically achieved in patients, and the dose required would be expected to lower potential toxicity while enhancing efficacy. Thus, given its previously reported systemic activity as a single agent $(13,38)$, and high body clearance rate (39), gemcitabine is a logical choice for both systemic and intravesical therapy; and several reports have confirmed its feasibility and tolerability for such application (40-42). For any intravesical application however, penetration of the molecule is crucial. Our current data and those from our previous studies $(15,17,43)$ demonstrate that gemcitabine can penetrate well in vitro into co-MCS UCB models with evidence of selective toxicity. We also have demonstrated here that TRAIL appears to have similar robust penetration to allow for potential intravesical administration of this agent alone or in combination with gemcitabine.

The presence of anti-apoptotic proteins such as members of the Bcl-2 family can also contribute to TRAIL resistance. Depending on cell type TRAIL apoptotic effect can be amplified by suppression of antiapoptotic molecules and/or upregulation of pro-apoptotic molecules. Importantly, we showed that during the first 24-72 h of gemcitabine-TRAIL therapy there was robust downregulation of $\mathrm{Bcl}-2$, accompanied by increased apoptosis (and cell death) in the UC cell lines investigated. In addition gemcitabine induced apoptosis with caspase-3, -8, -9, and PARP cleavage. These observations suggest that gemcitabine sensitizing effects in partially TRAIL-resistant cell lines might not be solely Bcl-2 dependent but could also be due to other mechanisms, including death receptor pathway and mitochondrial damage. In TRAIL-resistant cells (HT1376) gemcitabine or its combination with TRAIL had no effect on Bcl-2 level or TRAIL apoptosis. This could be due to the fact that activation of the TRAIL receptor can lead to activation of nuclear factor- $\kappa \beta$ which may subsequently mediate proliferation, invasion and metastasis (47). In addition, the HT1376 cell line appears to have a lower level of apoptotic proteins. Also post gemcitabine sensitization, TRAIL can induce a rapid negative-feedback loop that could downregulate TRAIL receptor expression thus allowing tumour cells to escape TRAIL mediated effect (28). In addition, we observed in this and other studies (unpublished data), that TRAIL can trigger the intrinsic pathway via $\mathrm{Bid}$ and that this pathway may be hampered or impaired in TRAIL-resistant UC cells. The tBid activation is cross-talk between the receptor-mediated pathway and mitochondria pathway that normally occurs when active caspase- 8 cleaves Bid. This then further supports the presence of alternative pathways that may resist or bypass apoptosis, or a situation where other anti-apoptotic proteins may substitute for Bcl-2 (after its downregulation) resulting in chemoresistance. Our data are, however, discordant with other observations where treatment of TRAIL-resistant cancer cells with gemcitabine enhanced TRAIL effect $(29,32)$. This enhancement was only observed in cells with partial resistance.

The gemcitabine effect on activation of the caspases could potentially permit combination therapy with TRAIL being administered after Bcl-2 downregulation with gemcitabine. By selectively inhibiting the caspase cascade with the two inhibitory peptides, our results demonstrated what could potentially happen with such a combination therapy and the near absolute need of these molecules for TRAIL-mediated apoptosis in UC cells. Apoptosis induced by TRAIL was dependent upon caspase activation as indicated by the effect of the caspase inhibitor peptides. However, inhibition of the caspases was ineffective in reducing gemcitabine-induced cytotoxicity. This observation suggests that these proteins are critical effectors of extrinsic apoptosis, whereas gemcitabine can activate caspase- 3 by caspase- 9 or independently through another mechanism either of which is sufficient for induction of apoptosis. In our studies pretreatment with gemcitabine enhanced TRAIL-mediated apoptosis suggesting that reduction of Bcl-2 had a more dominant impact than the extrinsic caspase pathway. Alternatively, gemcitabine may increase DR expression which we could not detect (data not shown) (54). As demonstrated, deficiency of one of the caspases examined can potentially result in compensatory activation of alternative (redundant) death activating pathways. As such the caspases should be the key rate limiting step as they are consumed in their activation and were thus chosen for targeting in these studies. However, the redundancy in the apoptotic pathways allows the process to proceed through upstream Bid or other mechanisms not yet elucidated. Bcl-2 appears to be a key or dominant regulator of both the intrinsic and extrinsic pathway in UCB.

In conclusion, we show here that treatment with TRAIL activates the caspase cascade to induce apoptosis in the UC 
cell lines. We also showed that gemcitabine enhanced the sensitivity of UC cells to TRAIL-induced apoptosis, and this was achieved in part through down-regulation of Bcl-2, and activation of the proteins (caspases, DISC) involved in the extrinsic (type II) death signalling cascade. The combined maximal stimulation of both the type I and type II pathways appears to overcome the survival pathway of PI3K-Akt pathway as evident by the lack of response to wortmannin. Furthermore, our data suggest that gemcitabine and TRAIL both appear to be able to penetrate deeply enough to allow for combination intravesical therapy in addition to systemic therapy. Thus, further preclinical and clinical studies are required to assess this therapeutic strategy for UC.

\section{Acknowledgements}

This study was supported by grants from the National Cancer Institute of Canada (NCIC no. 15105), the Alberta Cancer Board, and the Alberta Heritage Foundation for Medical Research. We wish to acknowledge the intellectual collaborative assistance of Dr Charlie Hao at Emory University, Atlanta, GA; and the technical support of Ms. Loretta Lucic on this project.

\section{References}

1. Gontero P, Marini L and Frea B: Intravesical gemcitabine for superficial bladder cancer: rationale for a new treatment option. Br J Urol 96: 970-976, 2005.

2. Ludwig AT, Moore JM, Luo Y, et al: Tumor necrosis factorrelated apoptosis-inducing ligand: A novel mechanism for Bacillus Calmette-Guerin-induced antitumor activity. Cancer Res 64: 3386-3390, 2004.

3. Simons M, Nauseef W and Griffith T: Neutrophils and TRAIL: Insights into BCG immunotherapy for bladder cancer. Immunol Res 39: 79-93, 2007.

4. McKnight JJ, Gray SB, O'Kane HF, Johnston SR and Williamson KE: Apoptosis and chemotherapy for bladder cancer. J Urol 173: 683-690, 2005.

5. Cohen GM: Caspases: The executioners of apoptosis. Biochem J 326: 1-16, 1997.

6. Hengartner MO: The biochemistry of apoptosis. Nature 407: 770-776, 2000

7. Sheridan JP, Marsters SA, Pitti RM, et al: Control of TRAILinduced apoptosis by a family of signaling and decoy receptors. Science 277: 818-821, 1997.

8. Tibbetts MD, Zheng L and Lenardo MJ: The death effector domain protein family: regulators of cellular homeostasis. Nat Immunol 4: 404-409, 2003

9. Jin X, Wu X-X, Abdel-Muneem Nouh MA and Kakehi Y: Enhancement of death receptor 4 mediated apoptosis and cytotoxicity in renal cell carcinoma cells by subtoxic concentrations of doxorubicin. J Urol 177: 1894-1899, 2007.

10. Shankar S, Singh TR and Srivastava RK: Ionizing radiation enhances the therapeutic potential of TRAIL in prostate cancer in vitro and in vivo: Intracellular mechanisms. Prostate 61: 35-49, 2004.

11. O'Kane HF, Watson CJ, Johnston SR, et al: Targeting death receptors in bladder, prostate and renal cancer. J Urol 175: 432-438, 2006.

12. Hertel LW, Boder GB, Kroin JS, et al: Evaluation of the antitumor activity of gemcitabine (2',2'-Difluoro-2'-deoxycytidine). Cancer Res 50: 4417-4422, 1990.

13. Stadler W, Kuzel T, Roth B, Raghavan D and Dorr F: Phase II study of single-agent gemcitabine in previously untreated patients with metastatic urothelial cancer. J Clin Oncol 15: 3394-3398, 1997.

14. Moore M, Winquist E, Murray N, et al: Gemcitabine plus cisplatin, an active regimen in advanced urothelial cancer: A phase II tria of the National Cancer Institute of Canada Clinical Trials Group. J Clin Oncol 17: 2876-2881, 1999.
15. Kilani RT, Tamimi Y, Karmali S, et al: Selective cytotoxicity of gemcitabine in bladder cancer cell lines. Anticancer Drugs 13: 557-566, 2002.

16. Sun B, Moibi JA, Mak A, Xiao Z, Roa W and Moore RB: Response of bladder carcinoma cells to TRAIL and antisense oligonucleotide, Bcl-2 or clusterin treatments. J Urol 181: 1361-1371, 2009.

17. Kilani RT, Tamimi Y, Hanel EG, et al: Selective reovirus killing of bladder cancer in a co-culture spheroid model. Virus Res 93: $1-12,2003$.

18. Nicoletti I, Migliorati G, Pagliacci MC, Grignani F and Riccardi C: A rapid and simple method for measuring thymocyte apoptosis by propidium iodide staining and flow cytometry. J Immunol Methods 139: 271-279, 1991.

19. Xu ZW, Kleeff J, Friess H, Buchler MW and Solioz M: Synergistic cytotoxic effect of TRAIL and gemcitabine in pancreatic cancer cells. Anticancer Res 23: 251-258, 2003.

20. Cory S and Adams JM: The Bcl 2 family: regulators of the cellular life-or-death switch. Nat Rev Cancer 2: 647-656, 2002.

21. Miyake H, Hara I, Yamanaka K, Gohji K, Arakawa S and Kamidono S: Overexpression of $\mathrm{Bcl}-2$ enhances metastatic potential of human bladder cancer cells. Br J Cancer 79: 1651-1656, 1999.

22. Ye D, Li H, Qian S, Sun Y, Zheng J and Ma Y: Bcl-2/bax expression and p53 gene status in human bladder cancer: relationship to early recurrence with intravesical chemotherapy after resection. J Urol 160: 2025-2029, 1998.

23. Duggan BJ, Maxwell P, Kelly JD, et al: The effect of antisense $\mathrm{Bcl}-2$ oligonucleotides on $\mathrm{Bcl}-2$ protein expression and apoptosis in human bladder transitional cell carcinoma. J Urol 166: 1098-1105, 2001.

24. Danik M, Chabot JG, Mercier C, et al: Human gliomas and epileptic foci express high levels of an mRNA related to rat testicular sulfated glycoprotein 2, a purported marker of cell death. Proc Natl Acad Sci USA 88: 8577-8581, 1991.

25. Sensibar JA, Sutkowski DM, Raffo A, et al: Prevention of cell death induced by tumor necrosis factor alpha in $\mathrm{LNCaP}$ cells by overexpression of sulfated glycoprotein-2 (Clusterin). Cancer Res 55: 2431-2437, 1995.

26. Miyake H, Nelson C, Rennie PS and Gleave ME: Acquisition of chemoresistant phenotype by overexpression of the antiapoptotic gene testosterone-repressed prostate message- 2 in prostate cancer xenograft models. Cancer Res 60: 2547-2554, 2000.

27. Xu ZW, Kleeff J, Friess H, Buchler MW and Solioz M: Synergistic cytotoxic effect of TRAIL and gemcitabine in pancreatic cancer cells. Anticancer Res 23: 251-258, 2003.

28. Steele LP, Georgopoulos NT, Southgate J, Selby PJ and Trejdosiewicz LK: Differential susceptibility to TRAIL of normal versus malignant human urothelial cells. Cell Death Differ 13: 1564-1576, 2006.

29. Mom CH, Verweij J, Oldenhuis CNAM, et al: Mapatumumab, a fully human agonistic monoclonal antibody that targets TRAIL-R1, in combination with gemcitabine and cisplatin: a phase I study. Clin Cancer Res 15: 5584-5590, 2009.

30. Arts HJG, de Jong S, Hollema H, ten Hoor K, van der Zee AGJ and de Vries EGE: Chemotherapy induces death receptor 5 in epithelial ovarian carcinoma. Gynecol Oncol 92: 794-800, 2004.

31. Baritaki S, Huerta-Yepez S, Sakai T, Spandidos DA and Bonavida B: Chemotherapeutic drugs sensitize cancer cells to TRAIL-mediated apoptosis: up-regulation of DR5 and inhibition of Yin Yang 1. Mol Cancer Ther 6: 1387-1399, 2007.

32. Seol JW, Chaudhari AA, Lee YJ, et al: Regulation of DR-5 protein and mitochondrial transmembrane potential by gemcitabine, a possible mechanism of gemcitabine-enhanced TRAIL-induced apoptosis. Oncol Rep 18: 523-529, 2007.

33. Bold RJ, Chandra J and McConkey DJ: Gemcitabine-induced programmed cell death (apoptosis) of human pancreatic carcinoma is determined by Bcl-2 content. Ann Surg Oncol 6: 279-285, 1999.

34. Mizutani Y, Nakao M, Ogawa O, Yoshida O, Bonavida B and Miki T: Enhanced sensitivity of bladder cancer cells to tumor necrosis factor related apoptosis inducing ligand mediated apoptosis by cisplatin and carboplatin. J Urol 165: 263-270, 2001.

35. Lin T, Zhang L, Davis J, et al: Combination of TRAIL gene therapy and chemotherapy enhances antitumor and antimetastasis effects in chemosensitive and chemoresistant breast cancers. Mol Ther 8: 441-448, 2003.

36. Chou T, Motzer R, Tong Y and Bosl G: Computerized quantitation of synergism and antagonism of taxol, topotecan, and cisplatin against human teratocarcinoma cell growth: a rational approach to clinical protocol design. J Natl Cancer Inst 86: 1517-1524, 1994. 
37. Soriano AF, Helfrich B, Chan DC, Heasley LE, Bunn PA Jr and Chou TC: Synergistic effects of new chemopreventive agents and conventional cytotoxic agents against human lung cancer cell lines. Cancer Res 59: 6178-6184, 1999.

38. Witjes JA, Vriesema JLJ, van der Heijden AG, Peters GJ and Schalken JA: Pharmacokinetics of intravesical gemcitabine: A preclinical study in pigs. Eur Urol 44: 615-619, 2003.

39. Laufer M, Ramalingam S, Schoenberg MP, et al: Intravesical gemcitabine therapy for superficial transitional cell carcinoma of the bladder: A phase I and pharmacokinetic study. J Clin Oncol 21: 697-703, 2003.

40. Dalbagni G, Russo P, Sheinfeld J, et al: Phase I trial of intravesical gemcitabine in bacillus Calmette-Guerin-refractory transitionalcell carcinoma of the bladder. J Clin Oncol 20: 3193-3198, 2002.

41. De Berardinis E, Antonini G, Peters GJ, et al: Intravesical administration of gemcitabine in superficial bladder cancer: a phase I study with pharmacodynamic evaluation. Br J Urol 93: 491-494, 2004

42. Palou J, Carcas A, Segarra J, et al: Phase I pharmacokinetic study of a single intravesical instillation of gemcitabine administered immediately after transurethral resection plus multiple random biopsies in patients with superficial bladder cancer. J Urol 172: 485-488, 2004

43. Hanel EG, Xiao Z, Wong KK, Lee PWK, Britten RA and Moore RB: A novel intravesical therapy for superficial bladder cancer in an orthotopic model: Oncolytic reovirus therapy. J Urol 172: 2018-2022, 2004

44. Marini P, Denzinger S, Schiller D, et al: Combined treatment of colorectal tumours with agonistic TRAIL receptor antibodies HGS-ETR1 and HGS-ETR2 and radiotherapy: enhanced effects in vitro and dose-dependent growth delay in vivo. Oncogene 25: $5145-5154,2006$

45. Kaufmann SH and Earnshaw WC: Induction of apoptosis by cancer chemotherapy. Exp Cell Res 256: 42-49, 2000.
46. Younes A and Kadin ME: Emerging applications of the tumor necrosis factor family of ligands and receptors in cancer therapy. J Clin Oncol 21: 3526-3534, 2003.

47. Ishimura N, Isomoto H, Bronk SF and Gores GJ: Trail induces cell migration and invasion in apoptosis-resistant cholangiocarcinoma cells. Am J Physiol Gastrointest Liver Physiol 290: G129-G136, 2006.

48. Rokhlin OW, Glover RA, Taghiyev AF, et al: Bisindolylmaleimide IX facilitates tumor necrosis factor receptor family-mediated cell death and acts as an inhibitor of transcription. J Biol Chem 277: 33213-33219, 2002.

49. Muzio M, Chinnaiyan AM, Kischkel FC, et al: FLICE, a novel FADD-homologous ICE/CED-3-like protease, is recruited to the CD95 (Fas/APO-1) death-inducing signaling complex. Cell 85: 817-827, 1996.

50. Boldin MP, Goncharov TM, Goltseve YV and Wallach D: Involvement of MACH, a novel MORT1/FADD-interacting protease, in Fas/APO-1- and TNF receptor-induced cell death. Cell 85: 803-815, 1996.

51. Kischkel FC, Hellbardt S, Behrmann IGM, Pawlita MKP and Me P: Cytotoxicity-dependent APO-1 (Fas/CD95)-associated proteins form a death-inducing signaling complex (DISC) with the receptor. EMBO J 14: 5579-5588, 1995.

52. Muzio M, Stockwell BR, Stennicke HR, Salvesen GS and Dixit VM: An induced proximity model for caspase-8 activation. J Biol Chem 273: 2926-2930, 1998.

53. Hao C, Beguinot F, Condorelli G, et al: Induction and intracellular regulation of tumor necrosis factor-related apoptosis-inducing ligand (TRAIL) mediated apotosis in human malignant glioma cells. Cancer Res 61: 1162-1170, 2001.

54. Ohtsuki T, Kikuchi H, Kowithayakorn T, Sakai T and Ishibashi M: Death receptor 5 promoter-enhancing compounds isolated from Catimbium speciosum and their enhancement effect on TRAILinduced apoptosis. Bioorg Med Chem 17: 6748-6754, 2009. 